\title{
Vacuum Drying of Sessile Oak (Quercus Petraea) with Alternative Heating Methods
}

\author{
Suat ALTUN ${ }^{1 *}$, Mustafa Altay EROĞLU \\ ${ }^{1 *}$ Faculty of Technology, Karabuk University, Karabuk, 78100, Turkey \\ ${ }^{2}$ Institute of Natural and Applied Sciences, Karabuk University, Karabuk, 78100, Turkey. \\ *Corresponding author: saltun@karabuk.edu.tr
}

Received Date: 31.07.2017

Accepted Date: 24.08.2017

\section{Abstract}

Aim of study: This study was prepared to determine the optimum drying process as a result of application of different parameters of vacuum drying method which is one of the technical drying methods, and to evaluate drying quality of these methods.

Area of study: This study carried out at the Karabuk University in Karabuk, Turkey and the materials was obtained from the Karabük Yenice Forest Management Directorate.

Material and Methods: Sessile Oak (Quercus Petraea) lumbers in 80x20x2.5 cm were dried at $2 \mathrm{~m} \mathrm{sec}^{-1}$ air velocity using two different vacuum periods of 15 and 30 minutes, 2 different heating methods namely plated and IR (infrared) in the kiln were used. Ambient pressure was set at 300 mbar in vacuum periods and 800 mbar in heating periods.

Main results: It was observed that the longest drying time was 242 hours $(0.15 \% / h o u r)$ with drying in IR heating in 30 minutes periods and the shortest drying time was 126 hours $(0.22 \% /$ hour $)$ in IR heating with 15 minutes periods. It has been found that the drying time decreases with the decrease of the waiting time in the vacuum. It has been determined that while the drying methods with 15 minutes plated heating, 15 minutes IR heating and 30 minutes IR heating meet the standard (S) drying quality class requirements, drying made with 30 minutes plated heating has reached to the high quality (Q) drying class.

Research highlights: IR heating in vacuum drying of Sessile Oak can be used successfully. Shorter vacuumheating periods leads higher drying rates in vacuum drying. Vacuum drying of lumbers wit IR heating meet the standard (S) drying quality class requirements.

Keywords: Sessile oak, Vacuum drying, Infrared, Moisture change, Drying quality

\section{Sapsız Meşe (Quercus Petraea) Odununun Alternatif Isıtma Yöntemleri}

\section{ile Vakumlu Kurutulması}

\section{Özet}

Çalışmanın Amacı: Bu çalışma, teknik kurutma yöntemlerinden biri olan vakumlu kurutma yönteminin değişik parametrelerinin uygulanması sonucu en uygun kurutma sürecini belirleyebilmek ve bu yöntemlrin kurutma kalitesini değerlendirmek amacıyla hazırlanmıştır.

Çalışma alanı: Bu çalışma Karbük Türkiye’deki Karabük Üniversitesinde yürütülmüştür. Çalışmaa kullanılan material Karabük Yenice Orman İşletme Müdürlüğünden temin edilmiştir.

Materyal ve Yöntem: 80x20x2.5 cm boyutlarındaki Sapsız Meşe keresteler levhalı ve IR (infrared) olmak üzere 2 farklı ısıtma yöntemi, 15 ve $30 \mathrm{dk}$ olmak üzere iki farklı vakum periyodu kullanılarak $2 \mathrm{~m} \mathrm{sn}^{-1}$ hava hızı ile kurutulmuştur. Vakum periyotlarında ortam basıncı 300 mbar, 1sıtma periyotlarında ise 800 mbar olarak ayarlanmıştır.

Sonuçlar: Deney sonuçlarına bakıldığında en uzun kurutma süresinin 242 saat $(0.15 \%$ /saat $)$ ile 30 dk periyotlarda IR 1sıtma ile kurutma yönteminde, en kısa kurutma süresinin ise 126 saat (0.22\%/saat) ile 15 dk periyotlarda IR isitma ile kurutma yönteminde elde edildiği gözlenmiştir. Vakumda bekleme süresinin azalması ile kurutma süresinin de azaldığı saptanmıştır. $15 \mathrm{dk}$ levhalı ısıtma, $15 \mathrm{dk}$ IR ile ısıtma ve $30 \mathrm{dk}$ IR ile 1sıtma ile kurutma yöntemleri standart (S) kurutma kalitesi sınıfı gereklerini karşılarken, $30 \mathrm{dk}$ levhalı ısıtma ile yapılan kurutma denemesinin ise kaliteli (Q) kurutma sınıfına girdiği belirlenmiştir.

Araştırma vurguları: Sapsız Meşenin vakumlu kurutulmasında IR ile 1sıtma başarılı bir şekilde kullanılabilir. Daha kısa süreli vakum-1sıtma periyotları, daha yüksek kurutma orannları elde edilmesini sağlamıştır. Kerestelerin IR ısıtma ile vakumlu kurutulması yöntemi standart (S) kurutma kalitesi sınıfı gereklerini karşılamıştır.

Anahtar kelimeler: Sapsız Meşe, Vakumlu kurutma, İnfrared, Rutubet değişimi, Kurutma kalitesi 


\section{Introduction}

Despite the technological innovations of our time and the competition of the new materials being used, due to the advantageous properties (being highly resistant despite its lightness, ease of processing, lacquer and paint applicability, ability to absorb sound, creating a warm environment in the places it is used etc.) and its natural look, the wood material still maintains its importance as a raw material and an end product today and continues to be used. The success of the production depends on the proper drying wood material according to the standards up to the desired moisture level under the conditions of use. The subject of this study is to determine the optimum drying process as a result of applying the different parameters of vacuum drying by considering the drying defects (cracking, deformation etc.) which may arise with the drying of oak lumber. There are studies in the literature about oak lumber drying and vacuum drying of different lumbers.

Kantay (1978) has dried $72 \mathrm{~m}^{3}$ Çoruh oak of $25 \mathrm{~mm}$ thickness in 2 different kilns with 2 and $20 \mathrm{~m}^{3}$ capacity by classical drying method. In the experiments, green lumber and up to $45 \%$ pre-dried lumber were used. Drying times of green lumber were found to be 306-418 hours, drying times of pre-dried lumber were found to be 209-288 hours. Ünsal (2002) has dried the oak lumber of 50 $\mathrm{mm}$ thickness and $15-25 \mathrm{~cm}$ width with $60 \%$ initial moisture by conventional drying method at air velocity of $3 \mathrm{~m} \mathrm{~s}^{-1}$ in two different drying kilns with 70 and $100 \mathrm{~m}^{3}$ capacity up to $10 \%$ final moisture of content (MC). It has been found that drying in highcapacity kiln gives better results, with shorter drying times, that lumber has entered the high-quality drying category in terms of average MC and individual values.

Simpson (1987) noted that 2.5-inch thick oak lumber can be dried with satisfactory quality within 300 hours with continuous vacuum between hot plates. Neumann et al. (1993) found that beech, spruce, and Scots pine lumber can be dried three times faster by liquid-vapor vacuum drying than liquid atmospheric vacuum drying, while drying times of oak lumber are not different from conventional drying. On the contrary, Fohr et al. (1995), obtained $20-50 \%$ faster drying of a $40 \mathrm{~mm}$ thick oak by vacuum drying than in conventional drying. Jomaa and Baixeras (1997) have also dried oak lumber of $27 \mathrm{~mm}$ thickness in a periodic vacuum in 10 days when compared to the oak which can be dried in 30 days by conventional drying. Altınok et al. (2009) also reported that the final MC can be reached in a period that is one-third less by vacuum drying than that of conventional drying of pine and beech lumbers of $50 \mathrm{~mm}$ and $35 \mathrm{~mm}$ thickness. Chen and Lamb (2004) have succeeded in drying the green red oak lumber by vacuum drying at a drying rate of $0.32-2.2 \%$ hourly, without any color change.

In studies related to vacuum drying parameters, Dikmen et al. (2012) have dried their pine lumber with an average initial moisture of $45 \%$ in the vacuum drying kiln they have designed to $8 \%$ of the final MC, and determined that the most optimized drying conditions are at $50{ }^{\circ} \mathrm{C}$ drying temperature, 0.80 bar working pressure and 0.25 bar vacuum application for 10 minutes. Gök (2011) stated, in his study he made by using poplar, pine and oak lumber, that oak is the most suitable wood to be dried by vacuum drying and the most ideal operating conditions are $50{ }^{\circ} \mathrm{C}$ temperature and 0.9 bar pre-vacuum pressure.

In addition to the use of vacuum in lumber drying, alternative heating systems have also been studied. Jung et al. (2000) used mechanical compression and vacuum drying methods together to increase heat transfer during drying, and they dried white pine in 4 days, red pine and Western hemlock in 5 days and larch in 6 days from green state to $15 \%$ final MC. Lee and Hayashi (2000) dried, 3-inch thick Japanese cedar with end grain sides covered, by radio frequency vacuum drying method by vapor pre-treating it and found shorter drying times and less shrinkage values than conventional methods. Ananias et al. (2005) have modeled a liquid-vapor vacuum drying system to dry the radiata pine and confirmed the validity of the model by testing at 0.2 bar and $70{ }^{\circ} \mathrm{C}$. He et al. (2012, 2013) indicated that ultrasound assisted vacuum drying decreased the drying time of Chinese catalpa wood. Lopatin et al. 
(2014) found that when combined with contact vacuum drying, low radio frequency heating is an important method for expelling moisture in lumber and significantly reduces drying time in wood species with a moisture content of more than $25-30 \%$. They think that this method will reduce the risk of bending and cracking due to the balancing of moisture distribution inequality. Ünsal et al. (2012) determined that, when combined with vacuum, a high frequency drying system is a suitable method for drying lumber that is thicker than $10 \mathrm{~cm}$ from wood species that are susceptible to drying. With this method, they observed that the drying period could be reduced to 7-10 days depending on the type of wood and its thickness. According to the results they obtained, the drying cost of $1 \mathrm{~m}^{3}$ lumber decreased by half compared to the classical methods. Perre et al. (2004) stated that it is possible to vacuum-dry small test pieces with infra-red (IR) heating; Cserta (2012), has investigated the drying process and moisture dynamics of Norwegian Spruce lumber in 50-200 $\mathrm{mm}$ thickness under macroscopic level and controlled technological conditions, stated that IR radiation can heat the wood not only from the surface but from the inside as well.

Although there are many studies in the literature concerning vacuum drying with contact plate heating, there is little work on drying the lumber with alternative heating methods, especially infrared heating. This study has been prepared for the purpose of determining optimum drying process by examining the effects of vacuum drying using contactless plate heating and infrared radiation heating on drying qualities such as drying rate, moisture distribution, crack formation and casehardening taking into account the defects that may arise during the drying of oak lumber.

\section{Material and Method}

In this study, Sessile Oak (Quercus Petraea) obtained from Karabük Yenice Forest Management Directorate was used. $120 \mathrm{~cm}$ long, $30 \mathrm{~cm}$ wide and $3 \mathrm{~cm}$ thick lumber were obtained by plainsawn method from $45 \mathrm{~cm}$ newly cut logs. The lumbers were cut to $80 \times 20 \times 2.5 \mathrm{~cm}$ in accordance with the test kiln used by cutting and removing the cracks and excess in the endgrain and side parts. The initial moisture of lumber before drying experiments was determined according to TS EN 13183-1 standard.

\section{The structure of the drying kiln}

In the case of vacuum drying with plate heat, the heating is provided with 2 heating plates with $3000 \mathrm{~W}$ power placed on the outer wall of the drying boiler in the shape of a cylinder. Foil glass wool with a thickness of $8 \mathrm{~cm}$ was used to insulate the kiln from the outside (Fig 1a). In the tests of drying with infrared heating, heating was provided with 2 IR resistances in $300 \mathrm{~W}$ power parallel to each other thanks to a special mechanism built into the kiln. In this setup, a $1 \mathrm{~mm}$ thick polished stainless steel plate was installed by being bent inside the kiln so that the IR radiation could be reflected homogeneously throughout the kiln (Fig 1b). The air movement in the kiln is provided by a snailtype fan controlled by a dimmer switch. The temperature inside the kiln and the internal temperature of the lumber were monitored using a mineral insulated thermocouple and controlled with a digital thermostat. A vacuum pump with a liquid ring with $1.5 \mathrm{~kW}$ power generating capacity, 33 mbar and $5 \mathrm{~m}^{3}$ $\mathrm{h}^{-1}$ suction capacity was used to create a lowpressure environment in the kiln.

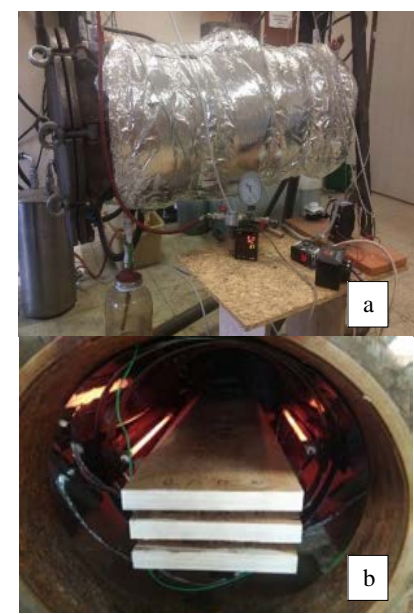

Figure 1. a) Overall view of the kiln during plate heating $b$ ) Position of the lumber in the kiln during the IR heating.

\section{Drying process}

In the drying tests, 3 pieces of lumber in measures of 80x20x2.5 cm were used in each group. The lumber with the end grain sides 
insulated, were weighed immediately before the drying process and weight of each was determined and photos were also taken for comparison after the test. In order to measure the internal temperature of the lumber during the drying period, a hole was drilled in the middle of the lumber and the mineral insulated thermocouple was inserted up to 1 $\mathrm{cm}$ depth. The lumber was inserted into the kiln in such a way that there would be gaps between them (Fig. 1b).

During the drying tests, periodic vacuum application was made in two different periods as 15 minutes and 30 minutes. Vacuum pumps were continuously operated in vacuum periods so that the internal pressure of the kiln would be 300 mbar. At the beginning of the heating period, fresh air was taken into the furnace, then the ambient pressure was set to 800 mbar. According to Kantay (1993), air movement velocity in technical drying varies between $1.3-2 \mathrm{~m} \mathrm{~s}^{-1}$ for softwoods and 2-4 $\mathrm{m} \mathrm{s}^{-1}$ for hardwoods woods depending on the type of lumber, the thickness of the lumber and the lumber moisture. Based on this information, the air flow in the furnace was set at $2 \mathrm{~m} \mathrm{sec}^{-1}$.

Kantay (1978) reported that high quality drying values were obtained in drying of oak species by applying kiln ambient temperatures of max $45{ }^{\circ} \mathrm{C}$ above fiber saturation point (FSP) and max $65{ }^{\circ} \mathrm{C}$ below FSP. During the experiment, the internal temperature of the lumber was taken into consideration and the temperature of the oak wood was kept at $50-55{ }^{\circ} \mathrm{C}$ until FSP and free water was discharged by following a balanced drying. When below FSP, the inner temperature of the lumber was raised to 70 $75^{\circ} \mathrm{C}$ and the highest temperature that can be applied is applied to evacuate the bound water in the cell wall.

During the tests, ambient temperature, lumber temperature and ambient pressure values were recorded every 15 minutes. The lumbers were weighed by being taken out of the kilns every 24 hours starting from the beginning of the drying process, daily moisture losses were recorded, notes were taken whether there were cracks, deformation etc. problems by taking photographs. At the end of the drying period, the heaters, fan and vacuum system were turned off, the valves were opened and the equalizing period was applied for 6 hours.

The mean final moisture, moisture distribution, crack formation and casehardening values of the lumber after drying according to the EDG (1992) standard have been determined to find the drying quality of the method applied at the end of each drying test. The drying quality classes were determined according to the obtained data. At the end of the drying process, the lumber taken out of the kiln was immediately weighted and then 4 pieces of each with a measure of $5 \times 5 \times 2.5 \mathrm{~cm}$ were cut (Figure 2a) from the middle parts of the lumber, the resulting moisture values of each lumber were determined in accordance with TS EN 13183-1 standard. The state of the drying stresses in the lumber was determined by the help of a trada pattern by taking 1 stress sample from the side of the middle and from the middle of the lumber (Figure 2b).

\section{Results}

Moisture change and daily average moisture loss values obtained in the drying tests performed in 15 and 30 minutes of vacuum periods are given in Figure 3 Figure 4. In both methods, the average daily moisture changes of the lumber from the initial moisture to the final MC have followed a regular course. Under FSP, drying occurred in a decreased ratio, mean daily moisture loss decreased with a balanced drying as it gets closer to the final moisture. During the drying period, the inner temperature of the lumber in vacuum periods and the ambient temperature values of the kiln were monitored and it was found that the ambient temperature decreased by $6-8{ }^{\circ} \mathrm{C}$ during the vacuum periods and the lumber temperature followed a linear course. With these results, it was observed that the lumber protected its heat and that it did not lose its internal temperature during the periods but ambient temperature in the kiln was fluctuated due to venting of the air in the kiln during vacuum periods. 


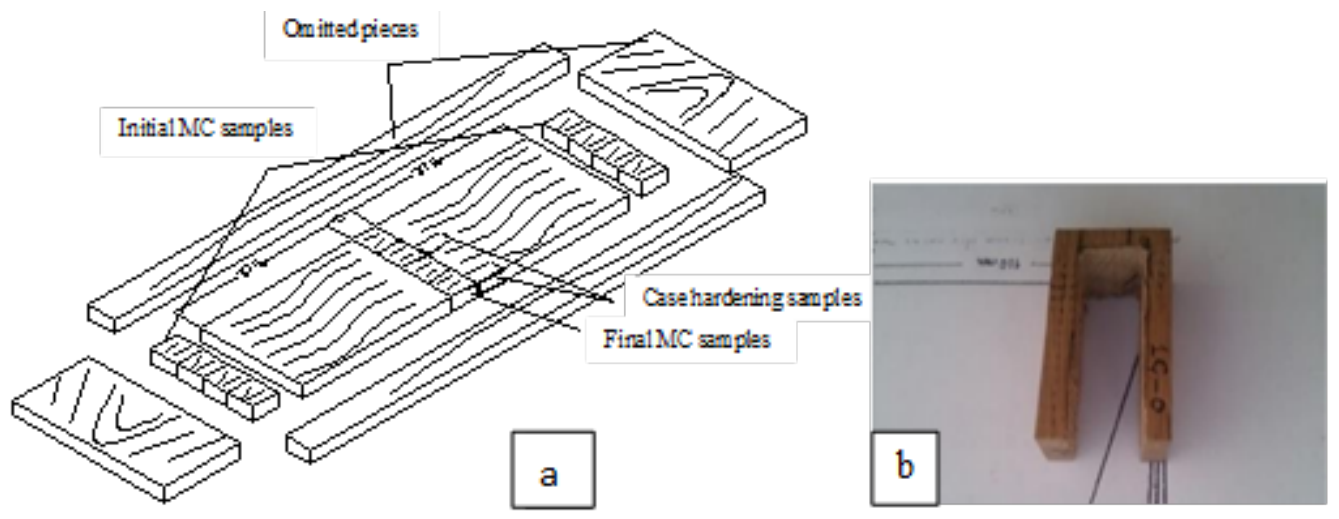

Figure 2. a) Samples taken from lumber before and after drying. b) Stress determination sample

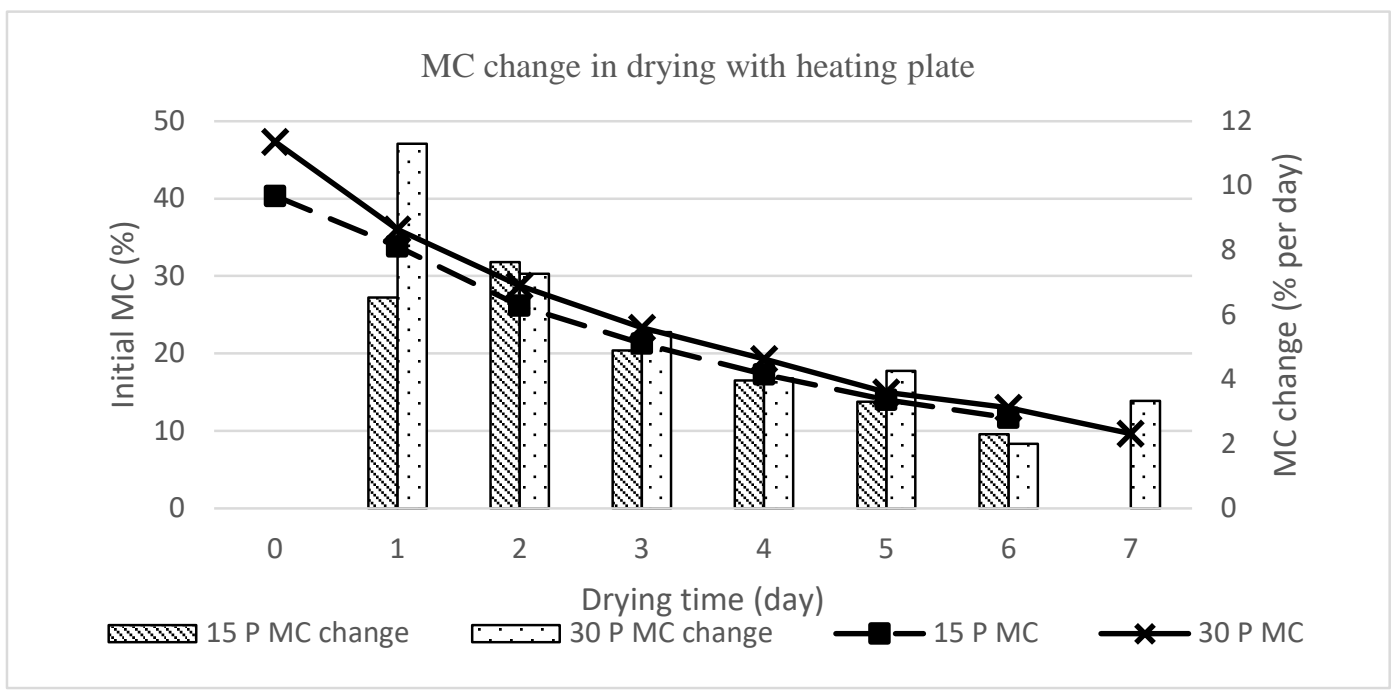

Figure 3. MC change in vacuum drying with heating plate

In tests made with plate heating in 15 minutes of vacuum periods (15-HP), the lumber with initial moisture content of $40.3 \%$ have reached a moisture of $11.7 \%$ at the end of the day 6 . The lumber that reached FSP at the end of day 2, has followed a decreasing drying course until final MC, as expected. The mean moisture loss on day 6 is $2.25 \%$. Moisture loss values of each of the lumber in the kiln were also examined and it was determined that the moisture difference between lumber is $\pm 1 \%$. It can be concluded that a homogeneous drying in the kiln was achieved according to the moisture change and daily moisture loss values of the dried lumber. It was found that the moisture in the outer edges of the lumber before drying was lower than the inner edges and when we have a look at the horizontal lumber moisture distribution there was an average of $1.8 \%$ difference between the edges and the middle section. The deviation between the target final MC (10\%) and average final MC $(11.7 \%)$ of the lumbers was determined as $1.7 \%$ and the maximum deviation between the target final $\mathrm{MC}$ and individual moisture measurements was $+4 \%$.

According to the results obtained from the stress determining samples taken after drying, it was determined that there is a slight casehardening in the lumber. One of the lumber was found to have a $120 \mathrm{~mm}$ long end crack, a $70 \mathrm{~mm}$ long and $3 \mathrm{~mm}$ deep surface crack, and another lumber found to have a small internal crack. Although deformation in accordance with the shrinkage anisotropy occurs in lumber after drying, no collapse has been detected. In the evaluation of the drying quality made in accordance with the EDG (1992) in the light of this data, it has been determined that the 
15-HP drying method meets the standard (S) drying quality class requirements.

In the drying tests made with 30 minutes vacuum periods with plate heating (30-HP), 9.7\% final MC has been reached from $47.3 \%$ initial moisture in 7 days. The daily moisture losses of the lumber were calculated to be $3.3 \%$ on the 7 th day showing a decreasing change. The moisture difference between the lumber in the kiln is $\pm 1-2 \%$. It can be told that a homogeneous drying in the kiln was achieved according to the moisture change and daily moisture loss values of the dried lumber. When the horizontal moisture distribution values after drying are considered $(< \pm 1 \%)$, it is determined that there is a balanced and desired distribution. The deviation between the target final MC (10\%) and average final MC $(9.7 \%)$ of the lumbers was determined as $0.3 \%$ and the maximum deviation between the target final MC and individual moisture measurements was $+2 \%,-4 \%$ in the evaluation of the drying quality.

Deformations in accordance with the shrinkage anisotropy and mild casehardening have been determined in the lumber after drying. While no internal cracks or collapse have been observed in the lumber, one was determined to have 2 surface cracks of 120 $\mathrm{mm}$ length and $3 \mathrm{~mm}$ depth. It has been concluded with this data that the 30-HP drying method meets the quality (Q) drying quality class requirements.

The results of drying experiments with infrared heating are given in Figure 4. In both methods, the drying curves followed a parallel course and under FSP, drying occurred in a decreased ratio, mean daily moisture loss decreased with a balanced drying as it gets closer to the final MC. However, since the initial moisture was lower in the 15-IR heating experiments (15IR), the final MC was reached in a shorter time. It has been determined that in the case of IR-heated drying, the moisture difference between the lumber in the kiln is $2-3 \%$, and a relatively homogeneous drying is achieved. In IR heating drying tests, it was observed that both the inner temperature of the lumber and the ambient temperature of the kiln during the heating and vacuum periods followed a linear course and both showed a $1-2{ }^{\circ} \mathrm{C}$ difference in the period passes. Since heat transfer with IR heating is provided by radiation, not by air, the ambient temperature in the vacuum period is not significantly affected.

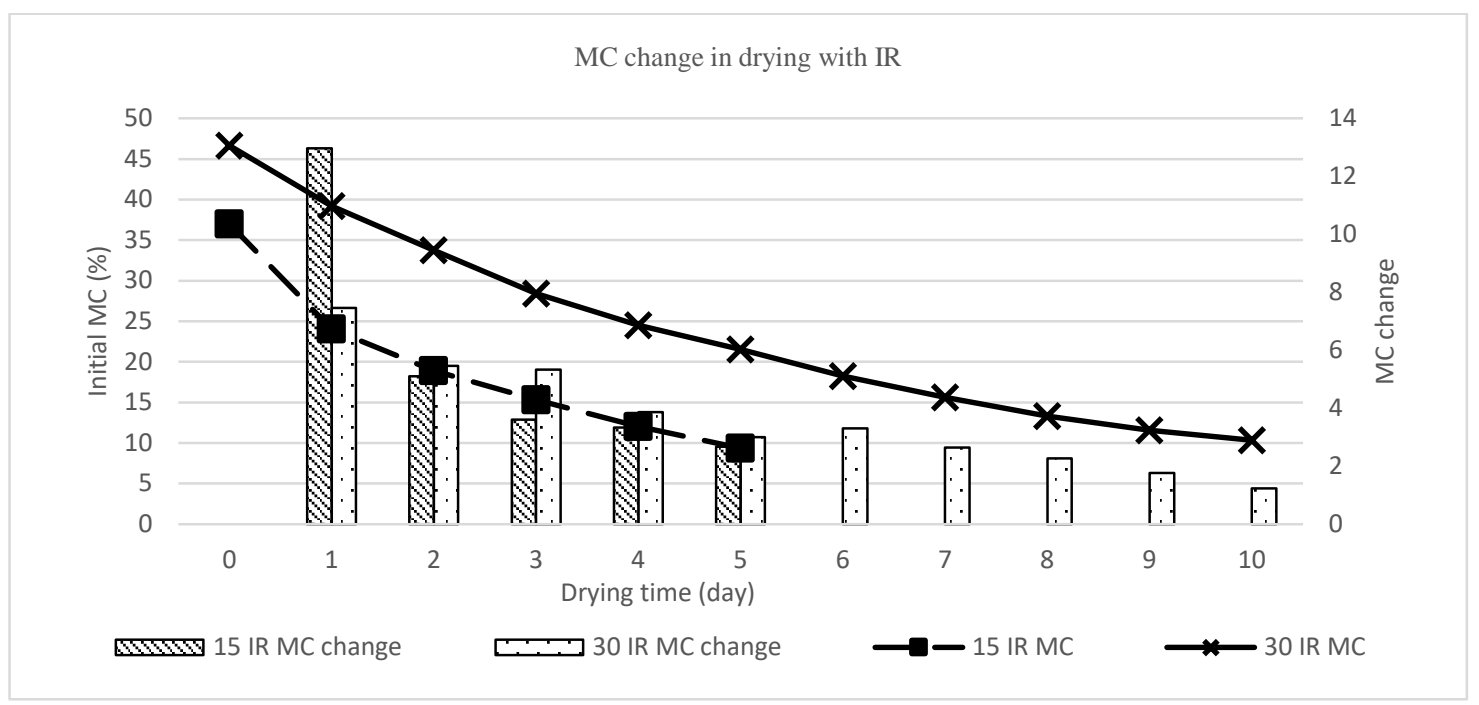

Figure 4. MC change in vacuum drying with IR heating

In 15-IR tests, it took 5 days to reach 9.3\% final moisture from the initial moisture of $37 \%$. Daily moisture loss showed a decreasing change, reached $2.6 \%$ on the 5 th day. The deviation between the target final MC (10\%) and average final MC (9.3\%) was determined as $0.7 \%$ and the maximum deviation between the target final MC and 
individual moisture measurements was $+5 \% /-4 \%$. When the horizontal moisture distribution values after drying were examined, $4.8 \%$ mean difference between the edges and the middle part was determined.

After drying with 15-IR method, it has been determined that there is a slight casehardening in lumber, one $70 \mathrm{~mm}$ long and $2 \mathrm{~mm}$ deep surface crack in one lumber, and one internal crack in one lumber. It has been concluded with the obtained data that the 15-IR drying method meets the standard (S) drying quality class requirements.

In 30-IR drying experiments the average initial moisture of lumber is $46.7 \%$. At the end of day 10 , the average moisture value reached $10.3 \%$. When we have a look at the daily moisture losses of the lumber, an ordinary drying was determined and the final MC was reached by losing a little less moisture each day. The mean moisture loss on day 10 is $1.2 \%$. The deviation between the target final MC (10\%) and average final MC $(10.3 \%)$ of the lumbers was determined as $0.3 \%$ and the maximum deviation between the target final MC and individual moisture measurements was $+6 \%,-4 \%$ in the evaluation of the drying quality. It is seen that the moisture on the outer edges of the lumber before drying is lower than the inner parts. When the horizontal moisture distribution values after drying were examined, 3\% mean difference between the edges and the middle part was determined.

It has been concluded that there was mild casehardening on lumber after drying. Surface cracks of 70 and $120 \mathrm{~mm}$ in length and $2 \mathrm{~mm}$ in depth were detected in one of the lumbers after drying. No collapse in the lumbers or internal cracks in the sample from which final MC detection samples were taken, were observed but deformation in accordance with the shrinkage anisotropy after drying was observed. It has been concluded with this data that the 30-IR drying method meets the standard (S) drying quality class requirements.

\section{Discussion and Conclusion}

Although many drying methods have been developed so that it can be dried up to the equilibrium moisture suitable for the climatic conditions of the place where it shall be used, each method has its own advantages and disadvantages. The most appropriate drying program should be selected and applied considering the type, density, thickness, shrinkage tendency of the wood material as well as cost, time and the conditions required for homogeneous drying.

In this study, it has been aimed to dry Sessile Oak lumber which is hard to dry and which has a high risk of cracking with two different heating methods (IR Resistance and plated heating, under periodic vacuum (15 min and $30 \mathrm{~min}$ )).

In four different methods, it was determined that the lumber forms a drying curve that is parallel from the initial moisture to the final MC. The drying curves obtained during the experiments are given in Figure 5. In 15-HP drying $11.7 \%$ final MC was reached from $40.3 \%$ initial moisture in 6 days (147 hours), in 30-HP drying 9.7\% final MC was reached from $47.3 \%$ initial moisture in 7 days (172 hours), in 15-IR drying 9.3\% final MC was reached from $37 \%$ initial moisture in 5 days (126 hours) and in 30-IR drying $10.3 \%$ final MC was reached from $46,7 \%$ initial moisture in 10 days (242 hours). Taking into account the total drying times, the drying time was shorter with 15 minutes vacuum periods. According to Dikmen et al. (2012), longer waiting period in the vacuum, directly makes the drying time longer. While the air movement accelerates the water movement from the inner layers to the surfaces by heating the water in wood material with the heat within the kiln, it removes the moisture from the surfaces of the dried wood material and allows the air with the ability to moisture intake reach the surfaces (Kantay, 1993). Since the air amount enabling the removal of water molecules reaching the surface of the lumber is small, water molecules remain on the surface of the lumber by being condensed. With the application of shorter vacuum periods, more fresh air can be taken into the furnace, so that evaporation can continue and more water can be thrown out with the air.

From initial moisture to FSP point, the moisture loss depends on the initial moisture but under FSP the drying is slowed down and 
average daily draying rate of $2-3 \%$ was achieved.

When the hourly drying rates were evaluated according to the methods applied, the fastest drying was obtained in 15-IR drying with $0.22 \%$ / hour. Drying with $30-$ IR was fairly slow ( $0.15 \%$ / hour) compared to other methods. With plate heating, even though drying with periods of 15 minutes is faster $(0.19 \% /$ hour $)$ it can be said that there is not a significant difference with 30 minutes drying $(0.21 \% /$ hour $)$.

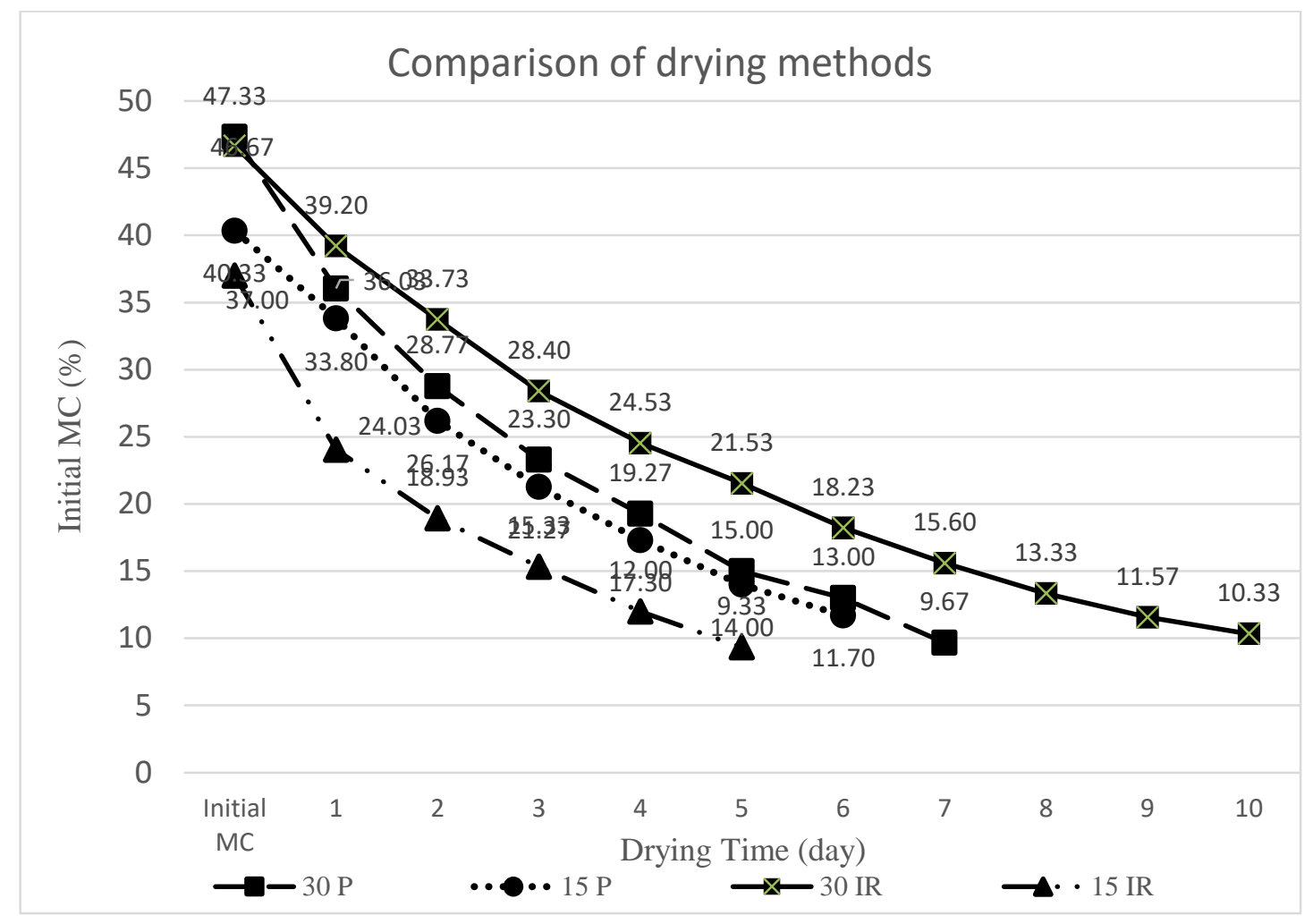

Figure 5. Average moisture changes according to drying method (\%).

Drying time in the drying of the lumber is an important factor on the cost of the drying process due to energy consumption. Since faster drying was achieved with 15-IR drying, it can be said that the energy consumed by the heaters and the vacuum pump during drying will lead to less energy consumption than the other methods and thus lower the energy costs.

All four methods applied are determined to have mild casehardening. In drying tests made with IR and plate in periods of 15 minutes, internal cracks, even though less, have been found. In 15-HP drying, end and surface cracks were found in one of the lumbers, in other methods, no end cracks were found, and results were obtained in accordance with quality (Q) drying class in terms of surface cracks.
No collapse was determined in the methods applied, deformations in accordance with the shrinkage anisotropy were observed after drying.

In light of all the obtained data, 30-HP method meets the requirements of quality (Q) drying class while other 3 methods were determined to meet the standard (S) drying quality class.

The comparison values with studies made on drying the oak species before have been given in Table 1. Unsal (2002) dried the 50 $\mathrm{mm}$ thick oak with $60 \%$ initial moisture with classical drying methods in different size kilns and achieved very low drying rate $\left(0.03 \%\right.$ hour $\left.{ }^{-1}\right)$ despite using higher temperature $\left(65^{\circ} \mathrm{C}\right)$ than the temperatures used in this study. The low drying rate is due to the high lumber thickness and the use of conventional technical drying methods. 
Kantay (1978) dried oak lumber with a similar thickness and initial moisture in 2 different types of kilns by conventional drying. Despite higher temperatures such as $65-70{ }^{\circ} \mathrm{C}$ were used; lower hourly drying rates $\left(0.14-0.19 \%\right.$ hour $\left.^{-1}\right)$ were obtained than the drying rates obtained in this study $\left(0.22 \%\right.$ hour $\left.^{-1}\right)$. However, dried lumber has been included in quality and high quality drying classes and it has been stated that it is possible to dry with relatively better quality. Brunner (1999) dried the oak lumber of similar thickness with the hot steam method at a faster drying rate $\left(0.26 \%\right.$ hour $\left.^{-1}\right)$ to similar final MC. Although achieving faster drying rates may be related to the drying method, Guilman et al. (1996) achieved a lower drying rate $\left(0.17 \%\right.$ hour $\left.^{-1}\right)$ with a similar hot steam method.

Table 1. Comparison of the results with the previous studies

\begin{tabular}{|c|c|c|c|c|c|c|c|c|c|c|}
\hline Reference & Wood & $\begin{array}{l}\mathrm{D} \\
(\mathrm{mm})\end{array}$ & Method & $\begin{array}{l}\text { Va } \\
\left(\mathrm{m} \mathrm{sn}^{-1}\right)\end{array}$ & $\begin{array}{l}\text { DT } \\
\text { (h) }\end{array}$ & $\begin{array}{l}\text { Tmax } \\
\left({ }^{\circ} \mathrm{C}\right)\end{array}$ & $\begin{array}{l}\mathrm{MCi} \\
(\%)\end{array}$ & MCf (\%) & $\begin{array}{l}\text { Drying rate } \\
\left(\% \mathrm{~h}^{-1}\right)\end{array}$ & ${ }^{\mathrm{e}} \mathrm{DQA}$ \\
\hline \multirow{4}{*}{ This study } & \multirow{4}{*}{$\begin{array}{l}\text { Sessile } \\
\text { (Quercus } \\
\text { Petraea) }\end{array}$} & \multirow{4}{*}{ oak25 } & 15-HP & \multirow{4}{*}{2} & 147 & 52 & 40.3 & 11.7 & 0.19 & $\mathrm{~S}$ \\
\hline & & & 30-HP & & 172 & 53 & 47.3 & 9.7 & 0.21 & $\mathrm{Q}$ \\
\hline & & & $\overline{15-I R}$ & & $\overline{126}$ & 42 & 37 & 9.3 & 0.22 & $S$ \\
\hline & & & 30-IR & & 242 & 43 & 46.7 & 10.3 & 0.15 & $\mathrm{~S}$ \\
\hline \multirow{2}{*}{$\begin{array}{l}\text { ÜNSAL Ö. } \\
2002\end{array}$} & Oak & \multirow{2}{*}{50} & $\begin{array}{l}\text { Tradiotonal } \\
\text { kiln drving }\end{array}$ & \multirow[t]{2}{*}{3} & 1380 & 65 & 60 & 9.7 & 0.03 & $\mathrm{~S}$ \\
\hline & Oak & & & & 1550 & 65 & 60 & 10.9 & 0.03 & $\mathrm{~S}$ \\
\hline \multirow{3}{*}{$\begin{array}{l}\text { KANTAY R. } \\
1978\end{array}$} & \multirow{3}{*}{\multicolumn{2}{|c|}{$\begin{array}{l}\text { Sessile oak } \\
\text { (Quercus } \\
\text { dschorochensis }{ }^{25} \\
\text { K.koch) }\end{array}$}} & \multirow{3}{*}{$\begin{array}{l}\text { Tradiotonal } \\
\text { kiln drying }\end{array}$} & & 209 & 65 & 45 & 8.5 & 0.19 & E \\
\hline & & & & & 288 & 65 & 45 & 7.5 & 0.14 & $\mathrm{E}$ \\
\hline & & & & & 277 & 70 & 45 & 7.5 & 0.14 & $\mathrm{Q}$ \\
\hline $\begin{array}{l}\text { BRUNNER } \\
\text { R.. } 1999\end{array}$ & $\begin{array}{l}\text { European } \\
\text { (Quercus } \\
\text { Robur) }\end{array}$ & $\begin{array}{r}\text { oak } \\
27\end{array}$ & Hot steam & - & 120 & - & 40 & 8 & 0.26 & - \\
\hline $\begin{array}{l}\text { GUILMAN } \\
\text { vd.. } 1996\end{array}$ & $\begin{array}{l}\text { European } \\
\text { (Quercus } \\
\text { Robur) }\end{array}$ & $\begin{array}{l}\text { oak } \\
27\end{array}$ & Hot steam & - & 230 & - & 50 & 10 & 0.17 & - \\
\hline
\end{tabular}

D: Timber thickness; Va: Air velocity; DT: Total drying time; Tmax: Max temperature; MCi: Initial MC; MCf: Final MC; DQA: Drying quality assestment

In light of this data, when the low ambient temperature, obtained drying periods and final MCs, hourly drying rates and drying quality classes are considered, it was concluded that it would be possible to dry the oak lumber with IR or heating plate under periodic vacuum.

According to the obtained test results, 30HP drying method can be preferred both in terms of drying quality $(\mathrm{Q})$ and hourly drying rate $(0.21 \%)$. However, the 15 -IR drying method can be used in terms of drying rate (0.22\%).

It is predicted, however, that the drying time can be further reduced by reducing the vacuum time. In their study, Hansmann et al.
(2008) have dried Eucalyptus Globulus, which has a high tendency to crack like oak in drying, at a low pressure (76 mbar) with a high frequency and dried from 58\% to $10.3 \%$ moisture in 5 days. Considering that the rate of hourly drying $(0.39 \%)$ they have obtained is higher than the values obtained in this study $(0.22 \%)$ can be resulted due to working at lower pressures, it can be suggested that drying experiments at lower pressures can be made for oak lumber drying.

\section{Acknowledgement}

This work was supported by Scientific Research Projects Coordination Unit of 
Karabük University (Project Number: KBÜBAP-17-BM-383).

\section{References}

Altınok, M., Küreli, İ., Serbes, T. (2009). Vakumlu ve klasik kurutma yöntemlerinin ahşap malzemenin bazı fiziksel ve mekanik özelliklerine etkisinin belirlenmesi. Politeknik Dergisi, 12(4), 271-278.

Ananias, R.A., Vallejos, S, Salinas, C. (2005). Estudio de la cinetica del secado convencional y bajo vacio del pino radiata, Ciencia Y Tecnologia, 7 (1), 3747.

Brunner, R. (1999). Vakuumtrocknung im wirtschaftlichkeitsvergleich. HolzZentralblatt, 57, 874-875.

Chen, Z.J., Lamb, F.M. (2004). A vacuum drying system for green hardwood parts. Drying Technology, 22(3), 577-595.

Cserta, E. (2012). Drying process of wood using infrared radiation. ( $\mathrm{PhD}$ Thesis, Universitas Hungariae Occidentalis, Hungary).

Dikmen, E., Sahin, A.Ș., Yakut, A.K. (2012). Deneysel bir kurutma sistemi tasarımı ve çalışma parametrelerinin incelenmesi. Isl Bilimi ve Tekniği Dergisi, 32(2), 81-88.

EDG. (1992). Recommendation on assesment of drying quality of timber, European Drying Group, Hamburg.

Fohr, J.P., Chakir, A., Arnaud, G., Peuty, M.A. (1995). Vacuum drying of oak wood. Drying Technology, 13(8-9), 1675.

Gök, S. (2011). Farklı sicaklıklarda çalışan vakumlu bir kereste kurutucu tasarımı ve kurutma parametrelerinin araştırllması (unpublished Master's Thesis). Süleyman Demirel Üniversitesi, Fen Bilimleri Enstitüsü, Isparta.

Guilman, C., Baixeras, O., Jomaa, W. (1996). Discontinous and convective vacuum drying of oak: experimental and modeling studies. Proceedings Of The 5th International IUFRO Wood Drying Conference, (s. 147-157) Quebec.

Hansmann, C., Stingl, R., Prieto, O.G., Lopez, C.B., Resch, H. (2008). Highfrequency energy-assisted vacuum drying of fresh eucalyptus globulus. Drying Technology, 26 (5), 611-616.
He, Z., Fei, Y., Yi, S., Gao, J. (2012). Effect of Ultrasound Pretreatment on Vacuum Drying of Chinese Catalpa Wood. Drying Technology, 30 (15), 1750-1755.

He, Z., Fei, Y., Peng, Y., Yi, S. (2013). Ultrasound-Assisted Vacuum Drying of Wood: Effects on Drying Time and Product Quality. Bioresources, 8 (1), 855863.

Jomaa, W., Baixeras, O. (1997). Discontinuous vacuum drying of oak wood: modelling and experimental investigations. Drying Technology, 15 (9), 2129-2144.

Jung, H.S., Lee, J.H., Lee, N.H. (2000). Vacuum-press drying of thick softwood lumbers. Drying Technology, 18 (8), 1921-1933.

Kantay, R. (1978). Türkiye'nin önemli bazı ağaç türleri kerestelerinin teknik kurutma özellikleri üzerine araştırmalar. İstanbul Üniversitesi Orman Fakültesi Dergisi, 28 (1), 139,140, 156, 158.

Kantay, R. (1993). Kereste Kurutma ve Buharlama. İstanbul: Ormancılık Eğitim ve Kültür Vakfi.

Lee, N.H., Hayashi, K. (2000). Effect of end covering and low pressure steam explosion treatment on drying rate and checking during radio frequency/vacuum drying of Japanese cedar log cross sections. Forest Products Journal, 50 (2), 73-78.

Lopatin, V.V., Goreshnev, M.A., Sekisov, F.G. (2014). Moisture transport in birch lumber at low radio-frequency and contact vacuum drying. European Journal of Wood and Wood Products, 72 (6), 779794.

Neumann, R., Mielke, A., Gios, P. (1993). Moisture transport in wood during convective vacuum drying. European Journal of Wood and Wood Products, 51 (3), 156-162.

Perre, P., Mosnier, S., Turner, I.W. (2004). Vacuum drying of wood with radiative heating: I. Experimental procedure. AIChE Journal, 50(1), 97- 107.

Simpson, W.T. (1987). Vacuum drying northern red oak. Forest Products Journal, 37 (1), 35-38.

TS EN 13183-1. (2012). Biçilmiş Yapacak Odun (Kereste) Parçasının Rutubet 
Muhtevası. Ankara: Türk Standartları Enstitüsü.

Ünsal, Ö., Güler, C., Mollamehmetoğlu, G. (2012). Ahsap kurutmada yüksek frekansvakum teknolojisi, Tarih Kültür ve Sanat Araştırmaları Dergisi, 1 (4), 310-318.

Ünsal, Ö. (2002). Teknik kurutmada firın boyutlarının ve hareket hizının kurutma kalitesi ve süresi üzerine etkisi, $\dot{\text { Istanbul }}$ Üniversitesi Orman Fakültesi Dergisi, 52 (1), 101,102, 105, 109. 